\section{SOI: 1.1 /TAS DOI: $10.15863 /$ TAS International Scientific Journal Theoretical \& Applied Science}

p-ISSN: 2308-4944 (print) e-ISSN: 2409-0085 (online)

Year: $2015 \quad$ Issue: $11 \quad$ Volume: 31

Published: $30.11 .2015 \quad$ http://T-Science.org
Oqiljon Abduazimov

$\mathrm{PhD}$ on sociological sciences The senior scientific researcher

Faculty of Social sciences

The Mirzo Ulugbek National University of Uzbekistan naumenko06@mail.ru

SECTION 30. Philosophy.

\title{
THE HIERARCHIC ANALYZING METHOD ON DETERMINING THE MONITORING OF THE SOCIETY'S IDEA THROUGH THE MASS MEDIA
}

\begin{abstract}
On providing the monitoring of the society' idea the role of Mass Media has been studied on the basis of hierarchic analyzing method. On determining the monitoring of the society's idea is divided into 3 factors such as: government Mass Media, private Mass media, nongovernmental Mass Media. Furthermore, the activity of Mass Media has been studied on 6 criteria: professionalism, independence, economic freedom, fairness, social activeness and impartiality. The activity of Mass Media in the different societies has been separated to 4 theoretical approaches: "Thermited press", "Tribonic press", "Transformed press" and "Tanazian press" and they have been compared by comparison.

Key words: Government Mass Media, private Mass media, nongovernmental Mass Media, professionalism, independence, economic freedom, fairness, social activeness and impartiality, "Thermited press", "Tribonic press", "Transformed press" and "Tanazian press".

Language: English

Citation: Abduazimov O (2015) THE HIERARCHIC ANALYZING METHOD ON DETERMINING THE MONITORING OF THE SOCIETY'S IDEA THROUGH THE MASS MEDIA. ISJ Theoretical \& Applied Science 11 (31): 8-12.
\end{abstract}

Soi: http://s-o-i.org/1.1/TAS-11-31-2 Doi: crossef http://dx.doi.org/10.15863/TAS.2015.11.31.2

On governing of each state and society the Mass Media has an important role. Because the Mass Media has an important place on forming of society's idea by actual social issues, and state has significant place on accepting important laws, related decrees. Influential feature, that I.Karimov, the President of the Republic of Uzbekistan has emphasized like this: "It is clear that, todays time that we are living and the new social attitudes put the following very important and actual tasks to the Mass Media, such as, being suitable to the demands of our society that changing and developing very fast, finding an answer to the issues that making people think and interrupt, forming the society's idea by putting them daily order" [1]. From this point of view, on providing of the monitoring of the society's idea, it is better to study the role of the Mass Media on hierarchic analyzing method by "4T theory of the press". Then the information of the Mass Media can be clear to the auditorium (attendee, spectator and reader) acceptable or unacceptable and effective or ineffective.

Originally, this method was produced [2] by an American scholar Tomas Saati, it is a mathematic instrument which based on systematic analyze. It may be used on accepting decisions on complex issues. Because the hierarchic analyzing method gives opportunity to seek the decisions of complex issues, to accept decision, to project rational systems on hierarchic principle, to compare and estimate the alternative variants by means of quantitative instructions [3]. We'll observe the mass communication processes on accepting the decision by hierarchic analyzing method on 4 stages. The sociology of mass communication is exMass Mediaed as the model of " $4 \mathrm{~T}$ theory of the press", and "the scale of importance" is used on ordering them and by comparing T.Saati's "9 scored scale".

The factors, criteria, participants(actors) told before are compared, their ratio is compared too. Telling on another way, the degree of importance of each stage of hierarchic analyzing method is ordered on the basis of comparing. Their coefficient is taken into consideration, the degree of importance is determined for the elements of this stage.

When this method is used the problem which is being studied will be systemized, and it is depicted on the form of tree and branch graph. According to 
the affective power and character of all the inclination and criteria which serve to the decision of the problem and the stages of the branch are distributed. In the last stage the alternative variants of the decision of the problem which are being studied, their accepted ones are determined according to the suitable coefficient and total result. By this state, the best accepted one of the alternative variants will be chosen, and then there will be an opportunity of accepting the decision according to the suitable coefficient.

Telling on another way, accepting the decision is accomplished on the following stages: 1) The hierarchic graph will be composed. 2) In each stage of hierarchy pair comparing matrix is put and the suitable coefficient (SC) of this stage is determined. 3 ) In the pair comparing matrix the phases of logical coincidence are checked and if the logical stage is out of order, it is corrected. 4) The results taken by the computer program are analyzed. In the marks given to them, the complete numbers mean positive and fractional numbers mean negative attitude. 5) The decision is accepted on the received information.

For this 5 staged hierarchic analyzing method is used.

1. Aim (problem). To determine the role of the Mass Media on providing the monitoring of the society's idea, i.e. it is the first stage.

2. The affects to the activity of the Mass Media. On providing the monitoring of the society's idea there are main 3 factors such as: governmental Mass Media, private Mass Media, nongovernmental Mass Media, this is the second stage.
3. The aims of the participants of the Mass Media activity. In this stage, each factor has its own aim, on forming the society's idea the activity of all the Mass Media is based on 6 criteria such as: professionalism, independence, economic freedom, fairness, social activeness and impartiality. In this stage each criterion is compared on the basis of the factors above told. This is the third stage.

4. The alternative variants for the Mass Media activity. This is the fourth stage, in this stage the activity of the Mass Media is separated to 4 theoretical approaches such as: "Thermited press", "Tribonic press", "Transformed press", "Tanazian press".

5. Commonness. In the finalizing stage it is concluded on the basis of the results of analyses, the best suitable variant is determined.

The factors which affect to the activity of the Mass Media, the participats' attitude to them and its aim are determined, the hierarchic analyzing method is done on the basis of hierarchic graph special computer program. In the first stage the ratio which affects to the problem, is determined in the related factors of the next stages. In this second stage the activity of the editorial office is separated to 3 directions such as: governmental Mass Media, private Mass Media and nongovernmental Mass Media. In this stage the Mass Media might be outlined with the following ordinal numbers such as: 1,2 and $3 ; 1^{\text {st }}$ is governmental, $2^{\text {nd }}$ is private and $3^{\text {rd }}$ is nongovernmental "Editorial offices".

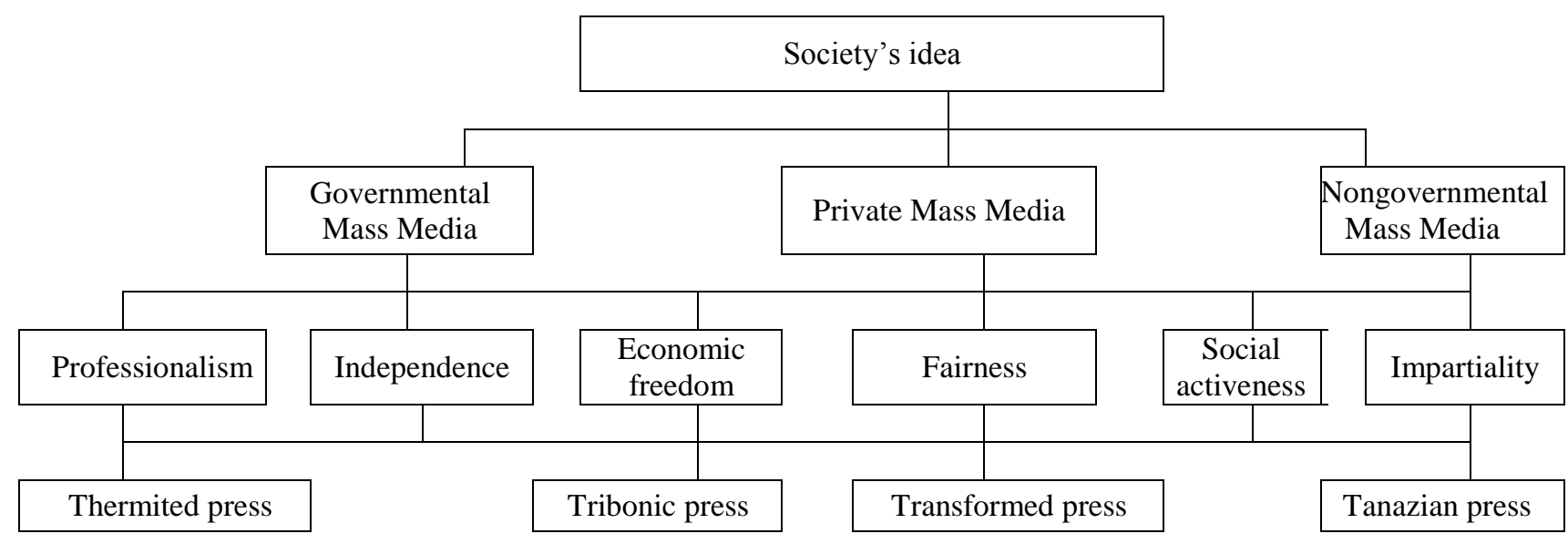

\section{Picture 1 - The hierarchic scheme of determining the monitoring of the society's idea} through the Mass Media.

In the $3^{\text {rd }}$ stage the main principles of the activity of journalism are based on 6 criteria such as professionalism, independence, economic freedom, fairness, social activeness and impartiality. In this stage each criterion is compared on the basis of the factors told above, and the participants' (journalist or auditorium) aims on materials are outlined on the basis of different criteria. They are as follows:

The professionalism of journalist: to seek information and skill of getting it, the ability of 
spreading the information, to activate the right and responsibility of the journalist, the state secret and the practice to be protected it, to follow the ethics of profession steadily in the creatural activity, to gain specialization of the field of journalism;

Journalist (editorial office) independence: the laws on the field and to respect the regulations of the editorial office, not to interfere with the creatural works of the editorial office, not to affect to a journalist, to achieve not to affect to the editorial office on different levels, to keep always the secret of the field of journalism;

The economic freedom of journalist (editorial office): promoters and the promoters on the basis of the establishing contract between editorial office, to follow the legal responsibilities of the editorial office and to provide, to order the promoters activity on financing sources of the editorial office, to accomplish the advertisements of the editorial office;

The struggle of journalist (editorial office) for the social fair: to achieve to activate the demands of the regulations of the editorial office, editorial office (journalist) in accordance with establishing documents, to follow the outlined tasks and responsibilities of editor-in-chief steadily;

The social activeness of journalist (editorial office): to strengthen mutual (contrary) relationships between editorial office (journalist) with auditorium (society), to achieve by protecting authorship right and similar rights, to organize a new Mass Media, i.e. to establish new editorial office;

The impartiality of journalist (editorial office): journalist's (editorial offices') providing the impartiality on brightening the different social problems (matters), not to let different deviant situation concerning object or subject, to strengthen social partners between state and society, to develop the social system through the democratic and citizenship institutions.

The affect of all events to the people's brain occurs on the basis of certain factors. From this point of view, in the informized society increasing the role of the Mass Media is also refered to the legal, economic, social-political factors. We have given the following question to the respondents in order to know the society's idea: "Which factors are important in order to increase the place of the press?" According to the results of the inquiry, $29,7 \%$ of respondents underlined that it is important "to accept the laws and under law documents related to the field as a legal factor". $18,6 \%$ of respondents has informed "to provide independent responsibility of editorial office as an economic factor". 9,1\% of respondents who took part in the inquiry, has reported "to multiply the different nongovernmental, nonentrepreneurship periodical publications as a social factor". According to the $6,3 \%$ of respondents approves to increase partial periodical publications as political factor.
In the $4^{\text {th }}$ stage the alternative variants of the Mass Media which might be the decision of the problem are compared with the "4T theory of the press", they are determined on the basis of the following factors:

1. "The theory of thermited press". The activity of Mass Media in the colonialism society the information is under the command of unique authoritarian (totalitarian) idea. This theory is divided into two on conditions: "The theory of authoritarian press" and "The theory of Soviet communistic press" [4]. For instance, the Uzbek press was formed as "Authoritarian press" in the time of Tsar Russia. After 1917, the policy of colonialism was continued again, the Uzbek press was under the command of the unique idea such as "Soviet communistic press". In 1906-1918 the Uzbek jaded press struggled for the independence as a democratic press. But the democratic activity of those editorial offices was prohibited and the Jadidists were sentenced to death in consequence of totalitarian policy.

2. "The theory of tribonic press" is formed and developed on the basis of the demands of the Mass Media citizenship society of the independent state. This situation on providing problems of society with information is called as the process of collapse in the thought of human being. The reason for this the following matters such as the changing of people's mind against the policy of colony and weird idea, getting lost the old stereotypes in the society's idea as a result of uniting the people. This theory is put in force on the basis of "The theory of libertarian press", "The theory of social responsibility in the press" and other theories of the press. In this situation certain peoples or certain nation who has a title became a unique state after defeating the colonial period. Such historic situations can be seen in the history of the Mass Media activity of the following countries such as The USA, Germany, Uzbekistan, Malaysia and India.

3. "The theory of transformed press". In the informized society on purpose of providing the society's idea with information fully, the reforms in the field of mass communication will be developed. In particular, the information will become open and closed ideological battlefield; it will be raised to the new stage from the point of quality. To this approach, American scholar Joseph Dominick's following theories can be bases such as "Developmental theory" [5] and "The theory of transformed press". For this reason as a result of uniting of different Mass Media activities such as editorial offices and types which close to each other, i.e. transforming of information market the editorial offices reorganize, transnational editorial offices will establish or their activity will change. The activities of the Mass Media of the following countries such as The USA, Germany, Russia, North Korea, 
Uzbekistan and other countries can be examples for this situation.

4. "The theory of tanazian press". It means that "dead press" faced to regression which erode the inner culture of the people or state by information threats serving the society of consumers and democratic ethical values of common humanity. Under the masks of "consumers demand", "consumers need" the Mass Media serves different weird ideologies, especially, encourages same sex marriages of citizens, different religious extremistic, hedonistic and chauvinistic ideologies. In the world of information on purpose of capturing citizen's (individ) brain, these negative situations are legally depicted, the danger of lobbistical movements increases which serves different economic, legal, political and military benefits. According to the result of inquiry, 38\% of respondents answered "Yes" to this question adding that when "mass culture" and other weird ideologies are propagated": "Can the society face to regression as a result of harming of the press to the human being spiritually and ethically?"; $37,3 \%$ of respondents answered "No", they said "The press does not connect to this issue and the society will never face to regression". $24,7 \%$ of respondents had no variants of answers to this question. So, it has been determined that the Mass Media might not only influence positively, but affect negatively to the individual as a result of propagating different weird idea and ideologies in the informed society.

In the last stage, that is, in the $5^{\text {th }}$ stage all the criteria become common as a result of comparing them, and then the final conclusion is given as a suitable variant.

Comparing of hierarchic elements is carried out in the following order: firstly aim (problem), then in comparing elements of the $2^{\text {nd }}$ stage, pair comparing scheme is completed facing to the substantial levels of factors, the suitable coefficient (SC) of experts are determined by a computer program (MPRIORITY 1.0) (1-scheme).

Comparing schedule on factors and SC .

Table 1

\begin{tabular}{|c|l|c|c|c|c|}
\hline № & \multicolumn{1}{|c|}{ Editorial offices } & $\begin{array}{c}\text { Governmental } \\
\text { Mass Media }\end{array}$ & $\begin{array}{c}\text { Private Mass } \\
\text { Media }\end{array}$ & $\begin{array}{c}\text { Nongovernmental } \\
\text { Mass Media }\end{array}$ & SC \\
\hline 1 & Governmental Mass Media & 1 & $1 / 2$ & $1 / 4$ & 0,1364 \\
\hline 2 & Private Mass Media & 2 & 1 & $1 / 3$ & 0,2384 \\
\hline 3 & $\begin{array}{l}\text { Nongovernmental } \\
\text { Mass Media }\end{array}$ & 4 & 3 & 1 & 0,625 \\
\hline
\end{tabular}

Then, from the point of the demands of each factor of the $2^{\text {nd }}$ stage, in order to evaluate the participants, the activity of Mass Media in the $3^{\text {rd }}$ stage elements relatively to 6 criteria such as: professionalism, independence, economic freedom, fairness, social activeness and impartiality to them the comparing matrix schedule will be completed.
That is, the suitable coefficient of the participants is determined by computer program on the basis of 3 factors.

On the basis of 3 factors the aims of the participants become common, the suitable coefficient (SC) of affecting factors are determined (Table 2).

The suitable coefficient of the participants.

Table 2

\begin{tabular}{|c|l|c|c|c|c|}
\hline № & \multicolumn{1}{|c|}{ Factors } & $\begin{array}{c}\text { Governmental } \\
\text { Mass Media }\end{array}$ & $\begin{array}{c}\text { Private } \\
\text { Mass Media }\end{array}$ & $\begin{array}{c}\text { Nongovernmental } \\
\text { Mass Media }\end{array}$ & SC \\
\hline 1 & Professionalism & 0,103 & 0,1921 & 0,1918 & 0,1797 \\
\hline 2 & Independence & 0,1698 & 0,1645 & 0,141 & 0,1505 \\
\hline 3 & Economic freedom & 0,2797 & 0,0445 & 0,0514 & 0,0808 \\
\hline 4 & Fairness & 0,1442 & 0,3599 & 0,2507 & 0,2621 \\
\hline 5 & Social activeness & 0,0741 & 0,0368 & 0,039 & 0,0432 \\
\hline 6 & Impartiality & 0,2289 & 0,202 & 0,3258 & 0,2830 \\
\hline
\end{tabular}

The participants of the elements in the next $4^{\text {th }}$ stage: separated comparing matrix pair schedules are completed on 6 criteria such as "Thermited press", "Tribonic press", "Transformed press", economic freedom, fairness, social activeness and impartiality.
Then the suitable coefficients (SC) of the field directions are determined by special computer program.

All the information having become common, the suitable coefficient of the Mass Media activity is 


\begin{tabular}{l|lrl|l|ll} 
& ISRA (India) & $=\mathbf{1 . 3 4 4}$ & SIS (USA) & $=\mathbf{0 . 9 1 2}$ & ICV (Poland) & $=\mathbf{6 . 6 3 0}$ \\
Impact Factor: & ISI (Dubai, UAE) $=\mathbf{0 . 8 2 9}$ & PUHL (Russia) $=\mathbf{0 . 1 7 9}$ & PIF (India) & $=\mathbf{1 . 9 4 0}$ \\
& GIF (Australia) & $\mathbf{0 . 5 6 4}$ & ESJI (KZ) & $=1.042$ & & \\
& JIF & $\mathbf{1 . 5 0 0}$ & SJIF (Morocco) $=\mathbf{2 . 0 3 1}$ & &
\end{tabular}

determined by using suitable coefficients which determined in the $2^{\text {nd }}$ stage (Table 3 ). Suitable index being under 0.20 on completing the schedules, conflicting situations are not permitted.

The suitable coefficient of mass communications.

Table 3

\begin{tabular}{|c|c|c|c|c|c|c|c|c|}
\hline № & $\begin{array}{c}\text { The alternative } \\
\text { variants }\end{array}$ & Professionalism & Independence & $\begin{array}{c}\text { Economic } \\
\text { freedom }\end{array}$ & Fairness & $\begin{array}{c}\text { Social } \\
\text { activeness }\end{array}$ & Impartiality & SC \\
\hline 1 & Thermited press & 0,265 & 0,0696 & 0,0777 & 0,0585 & 0,0806 & 0,0731 & 0,1044 \\
\hline 2 & Tribonic press & 0,1738 & 0,266 & 0,2773 & 0,1295 & 0,2702 & 0,4304 & 0,2617 \\
\hline 3 & Transformed press & 0,5147 & 0,5961 & 0,5299 & 0,5335 & 0,5785 & 0,4071 & 0,5043 \\
\hline 4 & Tanazian press & 0,0462 & 0,068 & 0,115 & 0,2783 & 0,0704 & 0,0892 & 0,1294 \\
\hline
\end{tabular}

\section{References:}

1. Karimov I (2015) Matbuot va ommaviy axborot vositalari xodimlariga. // "Xalq so'zi”, 2015, July 27, №126 (6309).

2. Thomas L. Saaty, Kevin P. Kearns (1993) Analytical planning. The Organization of Systems. - M.: Radio and connection, 1993.

3. Thomas L. Saaty (2008) Decision making with the analytic hierarchy process. Int.J.Services Sciences, Vol.1,No.1, 2008, pp.83-98.

4. Fred S. Sibert, Wilbur Schramm, Theodore Peterson (1998) Four theories of the press. National Press Institute rapic. - M.: "Vagrius", 1998.

5. Joseph R. Dominick (1996) The dynamics of mass communication. -5th ed. -N.Y.The McGraw-Hill Companies, Inc. 1996. -pp.65-67.

6. Karimov IA (2014) Doklad na zasedanii Kabineta Ministrov posvjashhennyj itogam social'no-jekonomicheskogo razvitija strany $\mathrm{v}$ 2013 goda takzhe ustojichivym napravlenijam jekonomicheskoj programmy 2014 goda //Narodnoe slovo.19 jan 2014.

7. Danilov AN (1997) Perehodnoe obshhestvo: problemy sistemnoj transformacii. Minsk: Universitetskoe, 1997.

8. Shtompka P (1996) Sociologija social'nyh izmenenij/Per. s angl. pod red. V.A. Jadova. Moscow: Aspekt Press, 1996

9. Nazarov MM (2003) Massovaya kommunikatsiya i obshchestvo. Vvedeniye $\mathrm{v}$ teoriyu i issledovaniya. - Moscow: Avanti plyus, 2003.

10. Le Roy WS (1992) Mass media / mass culture. - N.Y.: McGraw - Hill, Inc., 1992.; Graber, D.A. Mass media and American politics... - pp. 22. 